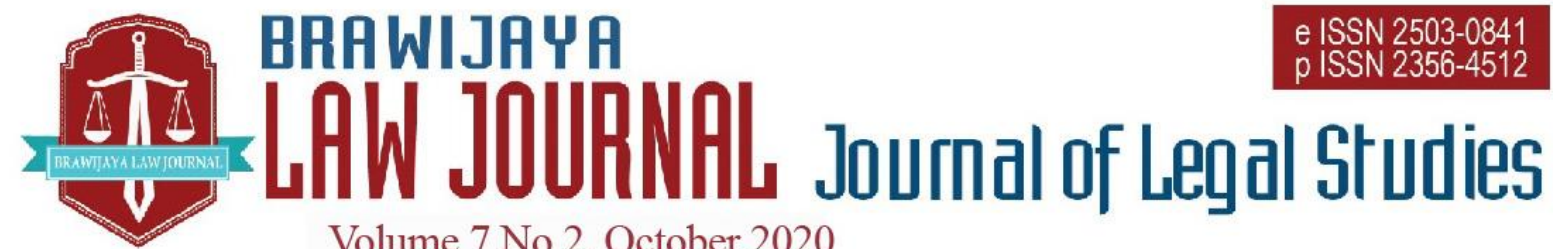

Volume 7 No 2, October 2020

Nationally Accredited No. 30/E/KPT/2018 Dated 24th October 2018

This work is licensed under a Creative Commons Attribution-NonCommercial 4.0 International License

\title{
Protection of Interests of Children: The Roles of Religions and Legal Regimes
}

\author{
Akintunde Abidemi Adebayo \\ Faculty of Law, Adekunle Ajasin University, Akungba-Akoko, Nigeria \\ Email: akintunde.adebayo@aaua.edu.ng
}

Submitted : 2019-12-24 | Accepted : 2020-09-10

\begin{abstract}
Religion provides the basis for the protection of human rights, namely, right to life, dignity of human person, right to property, among others. Without prejudice or disrespect to other religions, this paper focuses on Christianity religion and protection of rights of children considering their vulnerability. To this end, the Holy Bible provides for measures to safeguard, protect and ensure the good as well proper upbringing of children. Similarly, the United Nations Convention on the Rights of the Child, OAU Charter on the Rights and Welfare of the Child and the Child Rights Act provide for protection of rights of children. The essence of these provisions is to ensure the smooth running of the society and betterment of humanity. Therefore, this paper examines the salient provisions to safeguard and protect rights and interests of children in Christianity as well as under the aforementioned legal regimes. It concludes that while not undermining the significant role of laws in the protection of rights of children, religion plays an augmenting role of protecting the interests of children by instilling in members of the society, the needed respect for humanity and morality which is mostly lacking in the modern era. It recommends among other things that, government at all levels as well as religious leaders should give priority attention to the protection of children.
\end{abstract}

Keywords: child; human rights; christianity; religion; rights of children.

\section{INTRODUCTION}

Religions have provided the foundation and basis for human rights, mutual respect and cooperation, morality and peaceful coexistence in the society. They have special provisions and measures to safeguard and protect the interests of the vulnerable groups namely, children, women and the elderly ones. They emphasise dignity of humanity and life, morality, responsibilities and according respect/honour to one's parents, among others.

The protection of children from violence, ensuring the overall well-being of children are some of the salient tenets of many religions. In addition, they also play a vital role of augmenting the provisions of the legal frameworks on the protection of children through instilling of respect for life and humanity in members of the society. 
For the purpose of this paper, the discourse will without prejudice to other religions be limited to Christianity.

\section{LEGAL MATERIALS METHODS}

This research is a legal research using the doctrinal approach. Legal materials used in this research are primary legal materials and secondary legal materials. Primary legal materials include Christian child protection regulation inside the Holy Bible, Nigerian Constitution 1999 and Nigerian Child Rights Act 2003. Secondary materials include reports, journal articles and other relevant sources.

\section{RESULT AND DISCUSSION} Protection of Children in Christianity

In Christianity, the importance of children cannot be overemphasised. They are considered as precious gifts from God and not burden. ${ }^{1}$ To this end, there are many scriptures in both the Old and New Testaments of the Holy Bible which underscore the need and importance of protecting the interests and rights of the child as well as seeing to their utmost care and well-being.

A rights-based approach does not mean that children take on a role of simply demanding what they want and stop respecting adults. In fact, Christian community is the ideal environment for recognizing children's rights but also teaching them about the responsibilities that accompany rights. For example, where children have a right to be listened to, they also have a responsibility to listen to others; where they have a right to go to school, it is their responsibility to attend school and to do their best. Children should be given a chance to express both their rights and their responsibilities in the society. Some salient provisions of the Holy Bible will therefore, be examined in an attempt to do justice to the discourse on protection of interests of the child in Christianity. Therefore, these rights are to be viewed in the context of God's deep love for children and the high value he places on their well-being, and the contribution they can make.

Rights of children in the Bible can be divided into four categories namely, survival, protection, development and participation rights. That is include:

\section{a. Survival Rights}

In the Old Testament book of Isaiah, the Bible emphasises the safeguards for children and their descendants yet unborn. ${ }^{2}$ The story of Moses' birth in the book of Exodus is illustrative here. It shows how God uses all kinds of people to ensure the survival of a child. The statement, "the midwives feared God... they let the boys live" 3 shows that God values the lives of children. God already has plans for Moses' life and when Moses was born, he was protected by his mother, his sister, and even the daughter of Pharaoh. ${ }^{4}$ God's heart is for children to live and have all they need to survive and thrive.

The Bible has diverse accounts of children whose lives were in danger and who were enabled to survive with God's help. For instance, the widow's son was brought back to life by Elijah ${ }^{5}$ and by Elisha. ${ }^{6}$ Again in the New Testament, Paul brought a child back to life; "Paul went down, threw himself 
on the young man and put his arms around him."7

Jesus further demonstrated his love for children and desire for them to live during his earthly ministry. He healed children and brought them back to life in instances where they were dead. ${ }^{8}$ In the book of Mathew, Jesus informs his listeners that, "In the same way, your Father in heaven is not willing that any of these little ones should perish."9

On the need for parents to have and maintain a cordial and loving relationship with their children in order to ensure a peaceful coexistence and a violence free society, the Bible provides thus: "The Lord will turn the hearts of the fathers to their children, and the hearts of the children to their fathers..."10

The Holy Bible further makes it an obligation for parents, particularly mothers to comfort, love and look after the well-being of their children thus: "As a mother comforts her child, so will I comfort you; and you will be comforted over Jerusalem"11

Also, emphasis was laid on the sanctity of life, particularly children in the book of Deuteronomy of the Old Testament of the Holy Bible thus: "This day, I call heaven and earth as witnesses against you that I have set before you, life and death, blessings and curses. Now choose life, so that you and your children may live."12

God expressed his displeasure with children being deliberately killed or sacrificed $^{13}$ and God's heart is clear in Isaiah's prophecy that "Never again will there be... an infant who lives but a few days." 14 In light of the earlier mentioned scriptures condemning child sacrifice, it is

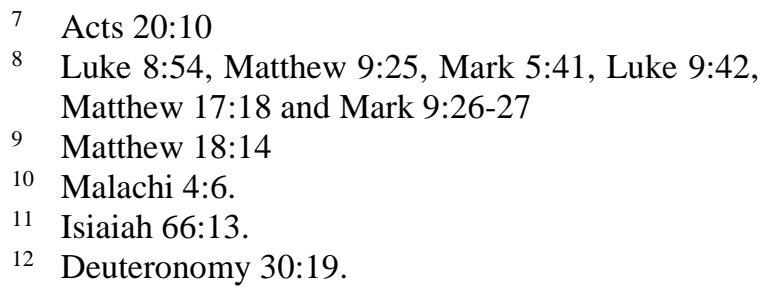

12 Deuteronomy 30:19.

important to stress that, God's command to Abraham to sacrifice his son, Isaac in the book of Genesis is not an endorsement of child sacrifice; God prevented the sacrifice from taking place and gave the command as an opportunity for Abraham to demonstrate his obedience. ${ }^{15}$ God's anger is provoked when a child's life is needlessly or deliberately taken, and indicate to us how precious the lives of children are to God. "The people of Israel and Judah have provoked me by all the evil things they have done... they built high places for Baal in the Valley of Ben Hinnom to sacrifice their sons and daughters to Molek, though I never commanded —nor did it enter my mind that they should do such a detestable thing and so make Judah sin."16

On care and provision for the child, the Holy Bible in the New Testament book of Mathew emphasises that a father is obliged and expected to love, care for and provide for his children. It therefore becomes the right of children to be cared for and provided for by their parents. "If you, then who are evil know how to give good gifts to your children, how much more will your father in heaven give good gifts to those who ask Him."17 Further, men were encouraged to have the size of family they can easily maintain and provide for. They must not have too many wives or children such that, they will not be able to provide for their needs, train, guide, teach and nurture. To this end, the New Testament of the Bible says: "a deacon must be the husband of but one wife and must manage his

13 Amos 1:13 and Psalm 94:6; Jeremiah 7:30-31, 19:5, and 32:35, Ezekiel 16:20, 20:31, and 23:37-39

14 Isaiah 65:20

15 Genesis 22; James 2:21-23.

16 Jeremiah 32:35

17 Mathew 7:11 
children and household well." 18 Also, in the second letter of Paul to the Corinthians, the Bible records thus: "...after all, children should not have to save up for their parents, but parents for their children." 19

\section{b. Protection Rights}

The story of Ishmael told in Genesis shows us the importance of protecting the interest of children to God, and how he can be intimately involved in keeping children safe. ${ }^{20}$ More importantly, the Bible places high premium and value on children. They are to be protected, loved, treasured and cherished by their parents and members of the society in which they live in. It says thus: "Whoever welcomes one of these little children in my name welcomes me." ${ }^{21}$ To further show the value and importance of children, child-like qualities were described as godly qualities. For instance, “...because you have hidden these things from the wise and learned and revealed them to little children..."22 Jesus further demonstrated his love for children and showed their importance in the book of Mark where $\mathrm{He}$ says: "...he said to them, let the little children come to me, and do not hinder them, for the kingdom of God belongs to such as these" 23 and "And he took the children in his arms, put his hands on them and blessed them." 24

Similarly, on the significance of children, the Bible describes them in diverse beautiful ways. For instance, in the book of Joel, they were described as prophets. ${ }^{25}$

\footnotetext{
181 Timothy 3:12.

192 Corinthians 12:14.

20 Job 24:9, Nehemiah 5:5, and Joel 3:3.; Joel 3:3; Isaiah 21:8-20.

21 Mark 9:37.

22 Luke 10:12; Mathew 11:25.

23 Mark 10:14.

24 Mark 10:16; Mark 10:15; Acts 2:39.

25 Joel 2:28.

26 Psalm 127: 3-5.

27 Psalm 128:3.
}

Further, they were described as heritage and reward from God. In the book of Psalms, children were described as arrows in the hands of a warrior and blessed is the man whose quiver is full of them for they shall not be put to shame when they contend with their enemies. ${ }^{26}$ Also, "...your sons will be like olive shoots around your table" 27 and "Children's children are a crown to the aged, and parents are the pride of their children." 28

The Bible clearly speaks out against the mistreatment of children. References were made to instances where children have been sold as slaves or traded like commodities, in the Bible. "They traded boys for prostitutes, they sold girls for wine to drink." 29

Vulnerable children particularly are to be protected with warnings against oppressing and mistreating the fatherless. ${ }^{30}$ Further, the Bible enjoins members of the society to protect children. ${ }^{31}$ In the Bible, the Israelites were instructed to ensure that vulnerable children are provided for. ${ }^{32}$ "Defend the weak and fatherless." 33

Further, as part of the protection of the interests of children, the Bible condemns those who cause harm or misguide children into destructive paths. "But if anyone causes one of these little ones who believe in me to sin, it would be better for him to have a large stone hung around his neck and be drowned in the the depth of the sea." 34

Protecting children is not only the responsibility of parents or those who work with children but the entire society. ${ }^{35}$ The

28 Proverbs 17:6; Proverbs 20:7.

${ }^{29}$ Isaiah 10:2, Ezekiel 22:7, Jeremiah 7:6 and 22:3, Zechariah 7:10 and Malachi 3:5; Matthew 18:6, Mark 9:42 and Luke 17:2

30 Deuteronomy 24:17-21

31 Deuteronomy 24:17-21

32 Psalm 72:4 and 82:3, Isaiah 1:17 and James 1:27

33 Psalm 82:3

34 Mathew 18:6.

35 Leviticus 20:22-25 
Bible shows that God wants every member of the community to be part of ensuring that the children around them are safe and protected from harm. ${ }^{36}$ God talks about how someone who has sacrificed his child should be punished, and says, if the members of the community ignore the actions of the said man, and if they fail to put him to death, God said he will himself set his face against him. Therefore, we all must make sure we are not ignoring situations of abuse and exploitation of children in our society.

\section{c. Development Rights}

Parents owe the duty to direct aright and shapen the lives and behaviours of their children properly through teachings, trainings and discipline. It is pertinent to note that, in Christianity, children are seen as prone to disorder and misbehaviour therefore, require constant corrections, guidance and discipline. Also, children are considered born with original sin, sinfulness in their inheritance so, education, chastisement, trainings are required to discipline and tame them. The Bible in the book of Proverbs says: "Train a child in the way he should go and when he is old, he will not depart from it." 37 The same duty of physical discipline and chastisement of children to make them responsible and law abiding members of the society was further emphasised thus: "Folly is bound up in the heart of a child but the rod of discipline will drive it far from him." 38 It is also written in another portion of the Holy Bible thus: "Do not withhold discipline from the child; if you punish him with the rod, he will not die." ${ }^{, 39}$

\footnotetext{
36 Leviticus 20:22-25

37 Proverbs 22:6.

38 Deuteronomy 22:15.

39 Deuteronomy 22:13.

40 Deuteronomy 22:14; Ephesians 6:4.
}

Similarly, "punish him with the rod, and save his soul from death." 40

Again, parents and their children were encouraged and commanded to be law abiding. Furthermore, parents particularly have an obligation to ensure that their children are law abiding and obedient to lawful authorities bearing in mind that if children and other members of the society abide by the extant laws, regulations and commandments, there will be peace and tranquillity in the home fronts and the larger society. Deuteronomy 32:46 says: "he said to them, take to heart all the words, I have solemnly declared to you this day, so that you may command your children to obey carefully all the words of this laws." In the same vein, the same book of Deuteronomy further states the importance and benefits of abiding by laws thus: "For I command you today, to love the Lord your God, to walk in his ways and to keep his commands, decrees and laws, then you will live and increase, and the Lord God will bless you in the land you are entering to possess." 41

The Holy Bible urges children to submit themselves to the guidance, teachings and trainings of their parents so that through these guidance and trainings, they can be moulded to become responsible adults who will pass on the same legacy to their descendants. In the book of Proverbs, it is written thus: "Listen to your father who gave you life and do not despise your mother when she is old." 42 Also, "The rod of correction imparts wisdom but a child left to himself disgraces his mother" 43 and "...teach them to your children and to their children after them." 44 Still on submission to parental

\footnotetext{
41 Deuteronomy 30:16.

42 Proverbs 23:22.

43 Proverbs 29:15.

44 Deuteronomy 4:9.
} 
guidance and trainings, the Holy Bible says: "These commandments that I give you today are to be upon your hearts, impress them on your children, talk about them when you sit at home, when you walk along the road, when you lie down and when you get up." 45 So also, in the New Testament book of Mark, children are encouraged to honour their parents and by extension, all and sundry in the society as this will promote orderliness and peaceful existence in the society. ${ }^{46} \mathrm{In}$ addition, children were encouraged to honour their parents and it is a condition for them to live long. It follows therefore that, there are rewards and blessings attached to that obligation. $^{47}$

\section{d. Participation Rights}

Children are to be given a sense of belonging and a right to participate in the affairs of the society. For instance, in the book of Second Kings, it was Naaman's servant girl who he had taken captive from Israel who gave Naaman the advice that if only he could see the servant of God, Elisha, he may be cured of his leprosy and Naaman listened and was cured. ${ }^{48}$ Sometimes, God works through children. Children and young people are therefore, encouraged to lead and to speak, and not to see their age as an obstacle.

Children are a blessing to a society and should be valued as such. ${ }^{49}$ Children are also a significant part of the religious community, participating along with adults. ${ }^{50}$ Children should be actively engaged and allowed to ask questions. ${ }^{51}$ The praise of children is powerful. ${ }^{52}$

The Bible gives many examples of children being used by God: Joseph was only 17 (Seventeen) when God was using him to help his father sherpeherd the flocks ${ }^{53}$ David was a "little more than a boy" when he fought Goliath, the mighty man of Philistine and defeated him. ${ }^{54}$ Samuel served God as a child and God chose to speak through him. ${ }^{55}$ Also, Josiah was 8 (eight) years old when he became King. ${ }^{56}$ Uzziah was 16 (sixteen) years old when he also started reigning as king. ${ }^{57}$

It is pertinent to point out that, it was a child who provided the 5 (five) loaves and 2 (two) fishes which Jesus used to feed the 5,000 people. ${ }^{58}$ Another clear illustration of God's willingness to use children and allow them participate in everyday life of the society is God choosing to restore mankind to Him by allowing Jesus to come to the world as a baby. ${ }^{59}$ "For to us a child is born, to us a son is given, and the government will be on his shoulders." 60

In general, it is apparent that the Holy Bible contains several provisions on protecting the interest and overall well-being of children considering the fact that they are precious yet vulnerable, therefore, need to be protected. The Old Testament portrays the child as one who is overly lacking in wisdom consequently, in need of constant guidance and training. The New Testament on the other hand, projects the child as precious gift

\footnotetext{
52 Psalm 8:2.

53 Genesis 37:2

541 Samuel 17:41

55 1 Samuel 2-3

562 Kings 22

572 Chronicles 26

58 John 6: 9-11; Jeremiah 1:7, 1 Timothy 4:12

59 Matthew 2:11, Luke 2:8-40

60 Isaiah 9:6
} 
from God that must be cherished, protected, loved and cared for.

\section{Protection of Rights of Children under International, Regional and National regimes}

The protection of rights of children under international, regional and national legal regimes is important. In examining these rights, this paper considers the United Nations Convention on the Rights of the Child (hereinafter referred to as the UN Convention on the Rights of the Child) as adopted by the $44^{\text {th }}$ session of the United Nations General Assembly in November 1989 and ratified by Nigeria as member state in March 1991. ${ }^{61}$ It also considers the provisions of the Organization of African Unity (now African Union) Charter on the Welfare of the Child (hereinafter referred to as the OAU Charter on the Welfare of the Child) to which Nigeria is also a signatory. ${ }^{62}$ It is the first regional treaty on the rights of children in the continent of Africa. ${ }^{63}$ It has similar provisions with the United Nations Convention on the Rights of the Child. These regional and international instruments seek to protect the child in all areas, provision of basic necessities of life and giving special attention and care to the vulnerable children. ${ }^{64}$

61 UN Convention on the Rights of the Child adopted by the $44^{\text {th }}$ session of the United Nations General Assembly in November 1989.

62 OAU Charter on Rights and Welfare of the Child, Doc. CAB/LEG/24.9/49 (1990) entered into force November 291999.

63 Ibid.

64 Agiobu-Kemmer, 'Baby Prisoners - How they fair in Captivity' Nigerian Guradian Newspaper of 19 June 2016 available online at <http://m.guardian.ng/sunday-magazine/babyprisoners-how-they-fair-in-captivity/> accessed 22 November 2019.

65 Nigerian Child Rights Act 2003.

66 Constitution of the Federal Republic of Nigeria 1999, Chapter IV. See also Child Rights Act 2003, s 3 .
Nigeria as a nation has also put in place several measures and framework towards the protection of the Nigerian child. Of particular note is the Child Rights Act ${ }^{65}$ which is meant to protect the rights of the child as guaranteed under the Constitution of Nigeria 1999. ${ }^{66}$ Since the issue of protection of children is contained on the residual list in the Nigerian Constitution, it is expected that states will domesticate it in their respective states having being enacted as an Act of the National Assembly of the Federal Republic of Nigeria. While some states have gone ahead to do so, a large number of them have not. $^{67}$

The rights of children are said to be divided into three major categories. They are: Welfare- which means the right to be provided for; Protection - it means children must be kept safe from all forms of dangers, exploitations or abuse and lastly, Autonomy - the right of children to make choices. ${ }^{68}$ Some of the basic rights of children are:

\section{a. Right to Life}

Every child shall have the right to life. ${ }^{69}$ The State will ensure the overall development and survival of the child. ${ }^{70} \mathrm{~A}$ child shall not be sentenced to death, irrespective of the crime. ${ }^{71}$ The life of a child could be threatened, jeopardised or taken in

67 OL Niyi-Gafar and OB Igbayiloye, 'Adopting a Rights-Based Approach Towards the Legal Protection of the Nigerian Child' (2016) 4 (1) Akungba Law Journal, 78.

68 Smaranda Olarinde, 'Reflections on the Basic Rights of the Nigerian Child under the Child Rights Act, 2003' (2005) 4 University of Ibadan Journal of Private and Business Law, 87.

69 The Constitution of the Federal Republic of Nigeria 1999, s 33; UN Convention on the Rights of the Child 1989, art VI (1) and (2). See also OAU Charter on the Rights and Welfare of the Child 1990, art V (1).

70 Child Rights Act 2003, s 4.

71 Ibid. 
several situations. In reality, a common situation in Nigeria whereby a child is allowed to stay with his or her imprisoned mother in prison custody thereby exposing such a child to starvation, sexual abuse, inhuman, cruel, degrading, unhygienic conditions and lack of access to health care which could lead to diseases and death of such a child is a violation of the right of the child to life. ${ }^{72}$ Children are the leaders of tomorrow, there is the need to protect the rights to life of every child. ${ }^{73}$

\section{b. Right not to be separated from Parents or Guardians}

A child shall not be separated from his parents or legal guardians except where it has been determined by a competent judicial authority that such a separation would be in the best interest of the child. ${ }^{74}$ It is trite that, this provision is a very laudable one as it will ensure that a child is not forcibly separated from his or her parents and that parents have the opportunity to nurture, care for and properly bring up their children. ${ }^{75}$ It will also ensure that children get the best of care, protection and development from their parents and legal guardians under a good atmosphere. ${ }^{76}$ Therefore, the common occurrence in many countries whereby children are forced to live with extended family members, friends or even given up to

\footnotetext{
S Agiobu-Kemmer, above n 64.

Ibid.

74 UN Convention on the Rights of the Child 1989 arts IX (1) and XX; OAU Charter on the Rights and Welfare of the Child 1990, art XIV; Child Rights Act 2003, ss 14, 16 and 27. See also S Agiobu-Kemmer, above n 64.

75 Bangkok Rules, r 58; RA Aborisade and OO Balogun, 'Dual Punishment: Mothers in Nigerian Prisons and their Children' (2016) 19 (1) African Journal for the Psychological Study of Social Issues, 1 .

76 OAU Charter on the Welfare of the Child 1989, art IV; RA Aborisade and OO Balogun, ibid, 1-2.
}

government welfare departments as a result of the disagreements, separation or divorce between their parents is unhealthy for the overall development and protection of the child so should be discouraged.

\section{c. Right to Freedom of Expression}

Every child shall be free to seek, receive and impart information within the ambit of the law. ${ }^{77}$ This right must not be curtailed in any form as every child must be free to express himself or herself, freely impart information and ideas without any fear, threat or insecurity. ${ }^{78}$ Where this right is exercised, it will further help in the mental, physical and psychological development of the child.

\section{d. Freedom of Thought, Religion and Conscience}

Every Nigerian shall have the right to thought, religion and conscience. ${ }^{79}$ It is pertinent to State that the Nigerian child is not exempted from the enjoyment of this right. ${ }^{80}$ However, the parents and legal guardians of children shall provide direction and guidance to their children when it comes to the enjoyment of this right. ${ }^{81}$ While admitting that this right exists, generally, it must be stated that children have limits to which they can independently practice, propagate or express their religious beliefs,

77 Constitution of the Federal Republic of Nigeria 1999, s 39 (1); UN Convention on the Rights of the Child 1989, art XIII. See also OAU Charter on the Rights and Welfare of the Child 1990, art VII.

78 S Agiobu-Kemmer, above n 64.

79 Constitution of the Federal Republic of Nigeria 1999, s 38; IKE Oraegbunam, 'Islamic Law Religious Freedom and Human Rights in Nigeria' (2012) 2 (1) African Journal of Law and Criminology, 1. See also OAU Charter on the Rights and Welfare of the Child 1990, art IX (1) and (2).

80 Child Rights Act 2003, s 7; S Agiobu-Kemmer above $\mathrm{n} 64$.

81 S Agiobu-Kemmer, above n 64. 
they need to be properly guided by their parents or legal guardians. ${ }^{82}$

\section{e. Right to Freedom of Association and Peaceful Assembly}

Every child shall have the right to freely associate with other children and to join peaceful assemblies within the limits of the law. ${ }^{83}$ For instance, a child should be free to associate with other children for recreation, for the purpose of education and learning, in schools, religious places of worship, residential areas, among others. It must also be stressed that, a child may need the guidance and consent of their parents or legal guardians in the exercise of this right and $^{84}$ the violation will be contrary to the standard expected for the treatment of children. ${ }^{85}$

\section{f. Right to Privacy and Family Life}

Every child shall have right to privacy, family life and correspondence. ${ }^{86}$ There shall not be any arbitrary or unlawful interference with the enjoyment of this right. ${ }^{87}$ They shall not be forced to live with persons other than their parents or legal guardians against their will or be in a place that they do not want to be. For instance, this right will be curtailed in a situation where an innocent child would have to stay and grow in prison custody because his or her mother is remanded in custody pending her trial in

82 RA Aborisade and OO Balogun, above n 75, 2-4.

83 UN Convention on the Rights of the Child, art XV; OAU Charter on the Rights and Welfare of the Child, art VIII; Child Rights Act, s 6.

84 S Agiobu-Kemmer, above n 64.

85 Ibid.

86 Constitution of the Federal Republic of Nigeria 1999, s 37; Child Rights Act 2003, s 8. See also Bangkok Rules, $r 64$.

87 UN Convention on the Rights of the Child 1989, art XVI; OAU Charter on the Rights and Welfare of the Child 1990, art IX. court or serving prison sentence as it common in Nigeria. ${ }^{88}$

\section{g. Right of Access to Information}

Every child shall be entitled to information from international and national sources which are capable of promoting the emotional, spiritual, moral, social and physical well-being of the child. ${ }^{89}$ It must be noted that any violation of this right will invariably have an adverse effect on the overall development of a child who finds himself or herself in this kind of situation as such a child may not be able to compete favourably with his or her peers who have supervised access to information that could help them to develop and grow. ${ }^{90}$

\section{h. Right to Education}

Every child shall have right to be educated. ${ }^{91}$ In doing this, there should be focus on the personality, talents, physical and mental abilities of each child. ${ }^{92}$ He or she should be taught about respect for human rights, preservation of societal culture and values, tolerance, mutual respect, honesty, loyalty, respect for the environment, among others. ${ }^{93}$ Having said that, the sad reality in many countries, particularly the developing ones is that many children of school age are out of school due largely to poverty, illiteracy, ignorance, among others. ${ }^{94} \mathrm{~A}$ child who not educated may end up as miscreant or criminal who will constitute a

88 RA Aborisade and OO Balogun, 4; S AgiobuKemmer, above n 64

89 UN Convention on the Rights of the Child 1989, art XVII.

90 UN Convention on the Rights of the Child 1989, art XVII.

91 Child Rights Act 2003, s 15.

92 UN Convention on the Rights of the Child 1989, arts XXVIII and XXIX.

93 OAU Charter on the Rights and Welfare of the Child 1990, art XI.

94 Child Rights Act 2003, s 15. 
problem for the society in future. ${ }^{95}$ Having posited that every child has a right to education, it is also imperative to state that the governments at all levels must put the appropriate measures in place such as provision of free and compulsory education up to tertiary education level, provision of studying materials, recruiting competent teachers to teach in schools, training and retraining of teachers, among others.

\section{i. Right to Health Care}

A child shall have the right to enjoy the highest attainable standard of health. ${ }^{96}$ The government therefore, must ensure it provides necessary health care services to the child, reduce infant and child mortality rate, combat diseases and malnutrition, provide safe drinking water, ensure quality health care for pregnant women and nursing mothers, among others. ${ }^{97}$ It has been observed that the Nigerian State and indeed many developing States have not faired well when it comes to the realization of this right. ${ }^{98}$ Most children do not have access to good health care; some of them consequently develop very dangerous diseases while others who are unlucky die. ${ }^{99}$ A large percentage of children in the developing countries are subjected to live in very unhygienic environments. 100 Sometimes, pregnant women lack adequate pre-natal attention and

95 Ibid. See also Agiobu-Kemmer, above n 64.

96 UN Convention on the Rights of the Child 1989, art XXIV; Child Rights Act 2003, s 13.

97 OAU Charter on the Rights and Welfare of the Child 1990, art XIV.

98 MA Araromi, 'Prisoners Rights under the Nigerian Law: Legal Pathways to Progressive Realization and Protection' (2015) 6 (1) Afe Babalola University Journal of Sustainable Development Law and Policy, 177-179, 170

99 S Agiobu-Kemmer, above n 64

100 Ibid.

101 RA Aborisade and OO Balogun, above n 75, 5.

102 MA Araromi, above n 89, 179.

103 Constitution of the Federal Republic of Nigeria 1999, s 42; UN Convention on the Rights of the sometimes left unattended to when delivering their babies. ${ }^{101}$ Some of the babies after delivery do not even get adequate medications and immunization. ${ }^{102}$

\section{j. Freedom from Discrimination}

Every child shall be free from discrimination on the account of the circumstances of his birth, parents' origin or race, ethnic, religious, sex, among others. ${ }^{103}$ Therefore, the common Nigerian practice of calling some children who were born outside wedlock 'bastards' will amount to discrimination against them based on the circumstances of their birth. Similarly, a situation whereby a child has to live with his or her mother by virtue of the mother's imprisonment will amount to a violation of the child's right not to be discriminated upon on any account. ${ }^{104}$ It will mean that such a child has been discriminated against based on the status of the mother as a prisoner. ${ }^{105}$ This is against the acceptable international standard. ${ }^{106}$

\section{k. Protection from Sexual Exploitation and Abuse}

Every child shall be entitled to protection from sexual abuse and exploitation. ${ }^{107}$ As of today, this particular right stands as the most violated right of the child in Nigeria going by the high statistics of

Child 1989, art XXX. See also OAU Charter on the Rights and Welfare of the Child 1990, art III; Child Rights Act 2003, s 10.

104 DI Dimkpa, 'The Plight of Women Inmates in Rivers State, Nigeria' (2011) 31 (1) Pakistan Journal of Social Sciences, 110-111.

105 Ibid.

106 OAU Charter on the Rights and Welfare of the Child 1990, art III; Child Rights Act 2003, s 10; UN Convention on the Rights of the Child 1989, art XXX.

107 UN Convention on the Rights of the Child 1989, art XXXIV. See also OAU Charter on the Rights and Welfare of the Child, arts XVI and XXVII; Child Rights Act 2003, ss 11 (a) -(b), 31 and 32. 
sexual assault and molestation of children, particularly the female gender. Apart from the aforementioned, it is also common in developing countries to find female children who are not up to the legal age of consent for marriage are also given out in marriage to male adults by their parents or legal guardians. Therefore, the parents or legal guardians of children must rise up to this challenge by providing adequate guide and protection to their children. ${ }^{108}$ They must ensure that their children are not in an environment where can be exposed to some dangerous elements and paedophiles who could easily abuse them sexually. Also, parents, particularly illiterates must be enlightened about the dangers of giving out a female child to an adult male in marriage. ${ }^{109}$

\section{Protection from Illicit Use of Narcotics and Drug Trafficking}

Every child shall be protected from the illicit use and trafficking of narcotics. ${ }^{110}$ For instance, children of female inmates of Nigerian prisons cannot be guaranteed of this right as they exposed to illicit use of narcotics considering the environment and the calibre of persons who often times such a child spends time with in the prison. ${ }^{111}$ This situation is not good for the overall development and future of the child. ${ }^{112}$ It must be said that the protection envisaged by this right will only be realized where a child grows up in a sane and serene society. ${ }^{113}$ Closely connected to the this right is the fact that children must be taught early in life

108 'Sexual Exploitation of Children in Nigeria Submission 29 March 2018' Human Rights Council $31^{\text {st }}$ Session (October - November 2018), 2-3.

109 'Country Report on Human Rights Practices 2017-Nigeria,' Document No. 1430111- US Department of State, available online at <http://www.ecoi.net> accessed 27 December 2018. about the dangers of using, dealing in or handling of hard drugs as these lessons with remain with them as they grow into adulthood. Likewise, parents or legal guardians of children must also provide good examples in this regard as children have the propensity to do what they see their parents or legal guardians do.

\section{CONCLUSION AND SUGGESTION}

Prior to the advent of what is now known as legal rights in the contemporary time, religion played a vital role of protecting and shielding children from disrespect to humanity and ill-treatment by their parents and members of the larger society. The Holy Bible particularly contains many provisions on protecting the interest and overall wellbeing of children considering the fact that they are vulnerable and need to be protected. The Old Testament particularly describes the child as one who is overly lacking in wisdom therefore, in need of constant guidance and training of their parents. The New Testament on the other hand, projects the child as a precious gift from God that must be cherished, protected, loved and cared for. Interestingly, strict adherence to the principles of religion particularly in the areas of respect for life and humanity could serve as the needed panacea to most of the challenges which children are faced with globally. Therefore, religion plays a significant role of protecting the interests of children by instilling in members of the society, the needed respect for humanity and

110 UN Convention on the Rights of the Child 1989, art XXXIII; OAU Charter on the Rights and Welfare of the Child 1990, art XXVIII; Child Rights Act 2003, ss 14 and 25.

111 Agiobu-Kemmer, above n 64.

112 Ibid.

113 UN Convention on the Rights of the Child 1989, art XXXIII; OAU Charter on the Rights and Welfare of the Child 1990, art XXVIII; Child Rights Act 2003, ss 14 and 25. 
morality which is currently lacking in this contemporary time.

In the same vein, in the bid to protect the interests of children, they are entitled to some basic human rights as provided for by the Constitution of Nigeria as well as other international and regional instruments including, OAU Charter on the Rights and Welfare of the Child, UN Convention on the Rights of the Child, among others. Therefore, it is safe to conclude that, there is a link between the provisions of the Holy Bible on protection of the interest of children and the fundamental human rights as found in various international, regional and national legal regimes.

\section{REFERENCE}

\section{Book and Report}

Women Consortium of Nigeria, and ECPAT International, Sexual Exploitation of Children in Nigeria Submission 29 March 2018" Human Rights Council $31^{\text {st }}$ Session, for the Universal Periodic Review of Human Rights Situation in Nigeria, to the Human Rights Council 31th Session (October - November 2018).

USDOS-US Department of State, 'Country Report on Human Rights Practices 2017 - Nigeria, Document No. 1430111- US Department of State, available online at $<$ http://www.ecoi.net>.

\section{Article}

OL Niyi-Gafar and OB Igbayiloye, 'Adopting a Rights-Based Approach Towards the Legal Protection of the Nigerian Child' (2016) 4 (1) Akungba Law Journal.

RA Aborisade and OO Balogun, 'Dual Punishment: Mothers in Nigerian
Prisons and their Children' (2016) 19 (1) African Journal for the Psychological Study of Social Issues. Smaranda Olarinde, 'Reflections on the Basic Rights of the Nigerian Child under the Child Rights Act, 2003' (2005) 4 University of Ibadan Journal of Private and Business Law.

IKE Oraegbunam, 'Islamic Law Religious Freedom and Human Rights in Nigeria' (2012) 2 (1) African Journal of Law and Criminology.

MA Araromi, 'Prisoners Rights under the Nigerian Law: Legal Pathways to Progressive Realization and Protection' (2015) 6 (1) Afe Babalola University Journal of Sustainable Development, Law and Policy.

DI Dimkpa, 'The Plight of Women Inmates in Rivers State, Nigeria' (2011) 31 (1) Pakistan Journal of Social Sciences.

\section{Regulation}

Holly Bible: Isiaiah 8:18; Genesis 33:5; Hebrews 2:13; Isiaiah 54:13; Exodus 1:17; Exodus 2; 1 Kings 17; 2 Kings 4; Acts 20:10; Luke 8:54, Matthew 9:25, Mark 5:41, Luke 9:42, Matthew 17:18 and Mark 9:26-27; Matthew 18:14; Malachi 4:6.; Isiaiah 66:13; Deuteronomy 30:19.; Amos 1:13 and Psalm 94:6; Jeremiah 7:30-31, 19:5, and 32:35, Ezekiel 16:20, 20:31, and 23:37-3; Isaiah 65:20; Genesis 22; James 2:21-23; Jeremiah 32:35; Mathew 7:11; 1 Timothy 3:12.; 2 Corinthians 12:14.; Job 24:9, Nehemiah 5:5, and Joel 3:3.; Joel 3:3; Isaiah 21:8-20; Mark 9:37; Luke 10:12; Mathew 11:25.; Mark 10:14; Mark 10:16; Mark 10:15; Acts 2:39; Joel 2:28; Psalm 127: 3-5; Psalm 128:3; Proverbs 17:6; Proverbs 20:7; Isaiah 10:2, Ezekiel 22:7, Jeremiah 7:6 and 
22:3, Zechariah 7:10 and Malachi 3:5; Matthew 18:6, Mark 9:42 and Luke 17:2; Deuteronomy 24:17-21; Deuteronomy 24:17-21; Psalm 72:4 and $82: 3$, Isaiah $1: 17$ and James $1: 27$; Psalm 82:3; Mathew 18:6; Leviticus 20:22-25; Leviticus 20:22-25; Proverbs 22:6; Deuteronomy 22:15; Deuteronomy 22:13; Deuteronomy 22:14; Ephesians 6:4; Deuteronomy 30:16; Proverbs 23:22; Proverbs 29:15; Deuteronomy 4:9; Deuteronomy 6:5-7; Colossians 3:2; Mark 7:10; Colossians 3:20; Ephesians 6: 1-3; 2 Kings 5:2-3; Ruth 4:15, Psalm 37:26, Isaiah 29:23; Deuteronomy 31:12-13, Joshua 8:35, Nehemiah 12:43, Psalm 148:11, Joel 2:16 and 10:7, Matthew 21:15, John 4:46-53, Acts 16:33, 18:7, 21:5; Joshua 4:6; Psalm 8:2; Genesis 37:2; 1 Samuel 17:41; 1 Samuel 2-3; 2 Kings 22; 2 Chronicles 26; John 6: 9-11; Jeremiah
1:7, 1 Timothy 4:1; Matthew 2:11, Luke 2:8-40; Isaiah 9:6.

Constitution of the Federal Republic of Nigeria 1999.

Child Rights Act 2003

Nigerian Child Rights Act 2003.

OAU Charter on Rights and Welfare of the Child, Doc. CAB/LEG/24.9/49 (1990) entered into force November 291999.

UN Convention on the Rights of the Child 1989.

\section{Internet}

Agiobu-Kemmer, 'Baby Prisoners - How they fair in Captivity' Nigerian Guradian Newspaper of 19 June 2016 available online at $<$ http://m.guardian.ng/sundaymagazine/baby-prisoners-how-theyfair-in-captivity/> accessed 22 November 2019. 